\title{
THE EFFECT OF COUNTRY RISK AND MACROECONOMIC ON JAKARTA ISLAMIC INDEX
}

\author{
Masrizal $^{\mathrm{a}}$ \\ Miftahurrahman ${ }^{b}$ \\ Sri Herianingrum ${ }^{c}$ \\ Yayan Firmansah ${ }^{d}$ \\ a,b Masters of Science in Islamic Economics, Faculty of Economics and Business, University of \\ Airlangga \\ ' Department of Islamic Economics, Faculty of Economic and Business, University of Airlangga \\ ${ }^{\mathrm{d}}$ Business Administration, Faculty of Economics and Management Sciences, International \\ Islamic University Malaysia \\ Email: masrizal-2017@pasca.unair.ac.id ${ }^{\text {a }}$; miftahurrahman565@gmail.com ${ }^{\text {b. }}$; \\ sriheria@gmail.com ${ }^{\text {c }}$; firmansah.yayan@live.iium.edu.my ${ }^{d}$
}

\section{ARTICLE HISTORY}

Received:

2 August 2019

Revised:

13 June 2020

Accepted:

14 June 2020

Online available:

30 June 2020

Keywords:

Country Risk, Macroeconomic,

Jakarta Islamic Index,

Vector Error Correction Model, Indonesia

*Correspondence:

Name: Miftahurrahman

E-mail:

miftahurrahman565@gmail.com

\section{ABSTRACT}

This study examines the impacts of Indonesia's country risks (i.e. financial risk, political risk, and economic risk), exchange rate, oil prices, and industrial production index on the Jakarta Islamic Index (JII). This reseacrch use monthly data from January 2003 to March 2016 with a quantitative research approach that applies Johansen Cointegration Test and Vector Error Correction Model (VECM) to see the long-term impact and response of shocks on certain variables. The findings show the existence of short-term and long-term causalities between macroeconomic variables and the Jakarta Islamic index. Specifically, in the long run, financial risk, oil prices, and exchange rates have a significant positive effect on Jakarta Islamic Index, while economic risks and industrial production index have a significant negative on Jakarta Islamic Index. This finding shows that investors consider financial risks, economic risks, and exchange rates in investments. This finding also tells the government that several important macroeconomic indicators need to be considered.

\section{INTRODUCTION}

The Islamic finance industry shows a fairly rapid development. The total amount of sharia financial assets was estimated at the US \$1.6 trillion at the end of 2012 , US $\$ 1.8$ trillion at the end of 2013 , ad US $\$ 2.1$ trillion at the end of 2014 . These assets are estimated at the US \$6.5 trillion in the year 2020 (Hammoudeh et al., 2014). Indonesia also continues to develop Islamic finance. This can be seen from the 
publication of the Global Islamic Finance Report which put Indonesia at 7th place in the Islamic Finance Country Index for 2017 (Global Islamic Finance Report, 2017). In terms of Islamic financial assets, in recent years Islamic finance in Indonesia has shown significant development.

Islamic Finance Development Report by ICD-Thomson Reuter shows that country with the largest Islamic financial assets was Iran. Meanwhile, Indonesia is included in the group of 10 countries with the largest financial assets along with Saudi Arabia, Malaysia, the United Arab Emirates, Kuwait, Bahrain, Qatar, Turkey, and Bangladesh. Based Indonesia financial services authorities (OJK) in 2017, the amount of Indonesia's Islamic financial assets took a position at 7th out of total world Islamic financial assets with a total of US \$81 billion, rising from the previous position which occupies the 9th position in the same report the previous year (Otoritas Jasa Keuangan, 2017).

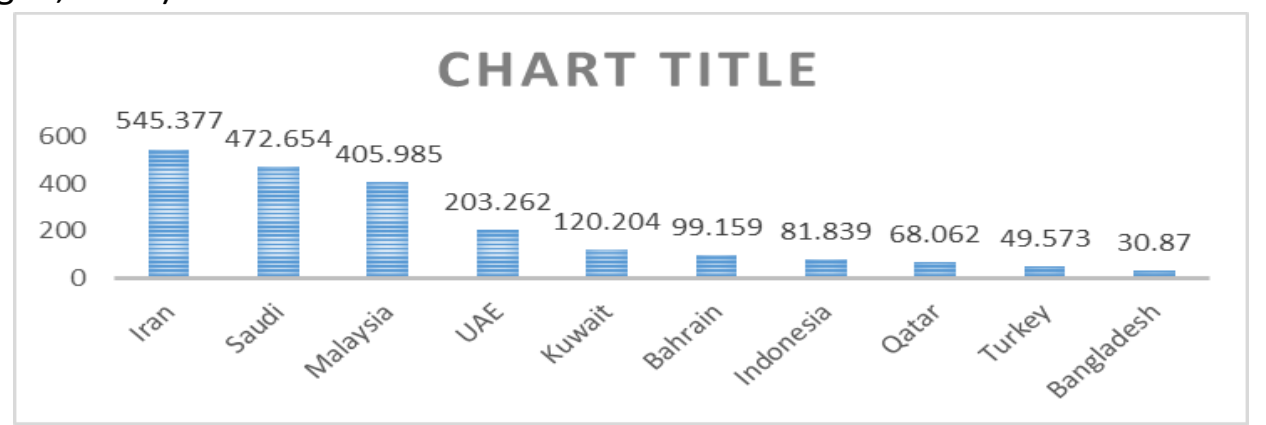

Figure 1. Islamic Financial Assets

Source: Financial Services Authorities (OJK)

The Islamic capital market is one of the means or products of Islamic finance. According to the principles of Islamic law, finance is not prohibited as long as the transactions do not across the provisions outlined by Islam. As one of the largest Muslim countries in the world, Indonesia has the potential to develop the Islamic finance industry. One of the measurements of the performance of Islamic capital markets in Indonesia is Jakarta Islamic Index (JII) which was established in July 2000. The shares in the JII group consist of 30 shares selected from shares according to Islamic law (Nasution, 2008). Based on an analysis conducted by the Indonesia Stock Exchange (Bursa Efek Indonesia or BEI) and Bapepam LK, sharia stocks increase every year, it can be seen from the chart of sharia stock movements below:

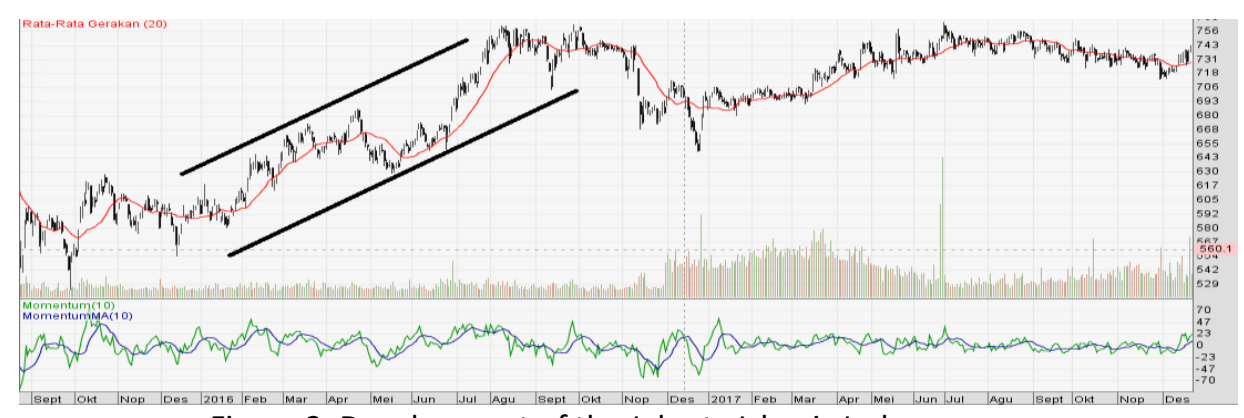

Figure 2. Development of the Jakarta Islamic Index

Source: Indonesia Stock Exchange (BEI) and Bapepam LK 
Based on the graph above, the long-term movement of the index shows a positive trend and has increased significantly, especially after the 2008 global crisis. Even for the short term from September to November 2016, price fluctuations still occur, but it increased for the period future. This shows the high awareness and interest of the public to invest in Islamic stocks. Bank Indonesia explains several factors to drive the capital market performance in Indonesia: 1) foreign investor perceptions towards the level of risk in Indonesia, 2) the interest rate differences that trigger capital inflows to obtain short-term profits, and 3) the stability of macroeconomics and the prospect of a significant increase in economic growth in the middle of a crisis. The fulfilled-factors could bring investors to invest in the capital market in Indonesia.

The study of factors influencing stock prices remains a popular area of financial research. Over the past few decades, the interaction of stock prices and macroeconomic variables has become an interesting subject among academics and practitioners. Over the last few years, several studies are conducted in developing countries such as Amihud \& Wohl (2004); Antonakakis et al. (2017); Hosseini et al. (2011); Hussainey \& Khanh Ngoc (2009); Hussin et al. (2012); Kara \& Karabiyik (2015); Kwon \& Shin (1999); Madura (2010); Maysami \& Koh (2000); Mnif (2017); Mohamed Asmy et al. (2010); Naifar (2016); Roubaud \& Arouri (2018); Vortelinos \& Saha (2016). These studies only focus on macro conditions. Based on these thoughts, this study will look back at stock price movements by including country risk variables (political, economic, and financial) that are not the main focus in the previous studies. Specifically, this paper investigates whether there is evidence of a long-term relationship between $\mathrm{JII}$ and selected macroeconomic variables namely country risk (financial risk, political risk, and financial risk), exchange rate, world oil, and production index (IPI) as a complement to the gaps from previous studies. It is hoped that the results of this study can be used as a reference for related parties to continue to optimize the potential of the Islamic capital market in Indonesia.

\section{LITERATURE REVIEW}

\section{Investment in Sharia Perspective}

According to the Quran (the central religious text of Islam), the purpose of all activities carried out by humans to ibtighai mardhatillah (asking for the pleasure of Allah). The activities that seek the pleasure of Allah are summum bonum of all kindness. Thus, one's investment and wealth in things that are not possible to be missed as one of them. In other words, the best investment is that he offers to achieve the pleasure of Allah (Ahmad, 2001).

Investment is one of the teachings of the Islamic concept that meets the tadrij process and the trichotomy of knowledge. This is explained in Al-Qur'an Surah alHasyr verse 18 as follows which means: "O you who have believed, fear Allah. And let 
every soul look to what it has put forth for tomorrow and fear Allah. Indeed, Allah is Acquainted with what you do." (Q.S Al-Hasyr: 18) (Quran.com, n.d.-a).

Lafaz waltanzur nafsum mā qaddamat lighad is interpreted by calculating and introspecting yourself before introspection, and seeing what you have saved for yourself from virtuous deeds (after here investment) as your provision for the day of charity reckoning on the Day of Judgment for your personal safety in front Allah. Thus Allah ordered all his servants who have faith to invest in the hereafter by doing good deeds from an early age as stock to face the day of reckoning. Besides that in the Quran Luqman verse 34, Allah states that no one in this universe can know what will be done, sought, and what events will happen tomorrow. This teaches all people are commanded to invest in the provision of the world and the hereafter. His words: "Indeed, Allah (alone) has knowledge of the Hour and sends down the rain and knows what is in the wombs. And no soul perceives what it will earn tomorrow, and no soul perceives in what land it will die. Indeed, Allah is Knowing and Acquainted." (AlLuqman: 34) (Quran.com, n.d.-b).

\section{Islamic Capital Market}

Capital market activities in Indonesia are regulated in Law No. 8 of 1995 concerning Capital Market (Capital Market Law). Article 1 point 13 of Law No. 8 of 1995 states that the capital market is an activity concerned with public offering and trading of securities, public companies related to the issuance of securities, and institutions and professions related to securities. The capital market law does not distinguish whether the capital market activities are carried out with Islamic principles or not. Thus based on the Capital Market Law, Indonesian capital market activities can be carried out both under sharia principles or not. To accommodate the needs of Muslims who want to invest in the capital market, capital markets must be formed based on sharia principles.

The Islamic capital market was officially launched on March 14, 2003, along with the signing of the MOU between Bapepam and Dewan Syariah Nasional (DSNMUI). Even though it was officially launched in 2003, the Islamic capital market instrument has been present in Indonesia since 1997, by the launch of Danareksa Syariah on July 3, 1997, by PT Danareksa Investment Management. Later, the launch of the Jakarta Islamic Index (JII) on July 3, 2000, aimed at guide investors who want to invest their funds in sharia. With the presence of the index, investors have been provided stock that can be used as a means of investing by applying sharia principles.

\section{Country Risk}

Country risk is a concept that explains the possibility of economic and political incidents that tend to produce deviations from the required or expected returns from investments made in a particular country, usually, these incidents have an inverse effect on investment (Kara \& Karabiyik, 2015). Several international agencies conduct 
country risk assessments and create databases to facilitate country risk analysis. The object of risk comes from the International Country Risk Guide (ICRG). This assessment provides risk indicators related to a particular country to help evaluate investment decisions, especially in the background of international trade and business. The risk database was created in 1980, which consists of financial, economic, and political risks. Each country's risk variable has different determinants, scores, and calculation weights. The table below illustrates the variables used in the country risk assessment.

Table 1

Country Risk Assessment

\begin{tabular}{|c|c|}
\hline Type of Risk & Country Risk Assessment \\
\hline \multirow[t]{2}{*}{ Political risk } & $\begin{array}{l}\text { Government Stability, Socioeconomic Conditions, } \\
\text { Investment Profile, Internal Conflict, External Conflict, } \\
\text { Corruption, Military in Politics, Religious Tensions, Law }\end{array}$ \\
\hline & $\begin{array}{l}\text { and Order, Ethnic Tensions, Democratic } \\
\text { Accountability, and Quality of Government } \\
\text { Bureaucracy. }\end{array}$ \\
\hline Economic Risk & $\begin{array}{l}\text { GDP per capita, Real GDP Growth, Annual Inflation } \\
\text { Rate, Government Budget Balance as a Percentage of } \\
\text { GDP, and the balance of Current Account as a } \\
\text { Percentage of GDP. }\end{array}$ \\
\hline Financial Risk & $\begin{array}{l}\text { Foreign Debt as a Percentage of GDP, Foreign Debt } \\
\text { Service as a Percentage of Exports of Goods and } \\
\text { Services, Current Account as a Percentage of Exports } \\
\text { of Goods and Services, Net International Liquidity as } \\
\text { Months of Import Cover, Exchange Rate Stability. }\end{array}$ \\
\hline
\end{tabular}

Source: International Country Risk Guide (ICRG)

The research from Kara \& Karabiyik (2015) was conducted to study the causal movements and the influence of country risks namely economic, political, and financial risks on the movements and volatility of BIST100 index stock prices. The relationship between variables was analyzed using a causality test based on Johansen's cointegration and vector error correction model (VECM). The findings confirm the short-term and long-term causality of the risk premium with stock prices. The regression results found that there was a negative effect on the economic, financial, and political risk premium on stock prices.

Vortelinos \& Saha (2016) study the impact of political risk on the stock and foreign exchange markets used a comprehensive sample of sixty-six countries and twenty political risk indicators that mostly cover the period of the financial crisis and recovery from May 2001 to April 2014. Their impact is assessed on returns, volatility, and a series of monthly frequencies. Evidence shows that Europe is largely at higher risk resulting from the economic crisis; whereas, political risk explains the high volatility and discontinuity in international stock markets and foreign exchange in other regions. Mnif (2017) found that political risk produces uncertain financial markets and clearer stock market cycles. Political instability caused by the shock of the Tunisian revolution caused a deviation in the stock cycle trend from its original 
path. This study gives importance to political risks and their significance to the volatility of the Tunisian stock market. Similar findings were found in a study conducted by Amihud \& Wohl (2004) which revealed an increase in the probability of starting and ending a war that affects the movement of stock prices.

\section{Exchange Rate}

According to Mishkin (2008), the exchange rate is the price of a country's currency with another country. Foreign exchange is also interpreted as a means of payment used to conduct international financial economic transactions and it has a record of the official exchange rate at the central bank. McEachren (2001) defines the exchange rate is the price of one currency measured by another currency. Exchange rates are determined by interactions between households, companies, private financial institutions, governments, and central banks that buy and sell foreign exchange.

Mishkin (2008) also states that demand for securities is influenced by many macroeconomic factors, including foreign exchange rates. An increase in the exchange rate affects companies in various ways. For companies with dollardenominated debt, dollar appreciation will greatly affect when the burden of paying off debt becomes greater. Furthermore, companies with the main activity on exports will be positively influenced by the increase in the dollar exchange rate. Changes in exchange rates will also affect the price of imported goods or services so that it will directly affect the profitability of the company.

The results of previous studies indicate that the exchange rate of the rupiah against the USD has a significant negative and positive effect. Mohamed Asmy et al. (2010) tried to examine the short-term and long-term causal relationships between the Kuala Lumpur Composite Index $(\mathrm{KLCl})$ and macroeconomic variables. The result shows that the exchange rate significantly affects $\mathrm{KLCl}$. This result also supports the research of Sakti \& Harun (2015) and Masrizal et al. (2019) states that in the long run there is a positive relationship between $\mathrm{JII}$ and the exchange rate.

Bahmani-Oskooee \& Saha (2016) believe that changes in exchange rates have an asymmetrical effect on stock prices. Furthermore, Blau (2017) assumes that exchange rate volatility is associated with greater kurtosis, and more negative tendencies of stock returns (Blau, 2017). The negative effect of the exchange rate on the stock index was also found in studies conducted by some researchers (Delgado et al., 2018; Rachmawati \& Laila, 2015; Suciningtias \& Khoiroh, 2015; Syarif \& Asandimitra, 2015).

\section{World Oil Price}

Another macroeconomic factor that plays an important role in determining stock prices is world oil. Oil prices are expressed as a real proxy for economic activity. Where an increase in oil prices on the international market will cause low economic activity in all sectors which will cause stocks to fall back. Oil is the main input for most 
companies, higher oil prices increase production costs, reduce cash flow income, and dividends. Second, higher oil prices can lead to overestimation of inflation and higher nominal interest rates.

The theoretical relationship between oil prices and stock returns can be positive or negative. Roubaud \& Arouri (2018) found that oil plays an active role in transmitting price shocks to the stock market. Huang et al. (2011) believe that oil price volatility has a significant effect on stock returns. This result is also in line with the study of Narayan \& Narayan (2010) findings which found a positive and significant impact of oil prices on stock prices.

Raza et al. (2016) discuss the asymmetrical damages of gold prices, oil prices, and stock volatility in developing countries. Empirical results show that the price of gold has a positive impact on the stock market prices of large economies and a negative impact on the stock markets of Mexico, Malaysia, Thailand, Chile, and Indonesia. Oil prices have a negative impact on the stock markets of all developing countries. The same thing was also stated by Antonio et al (2013) that oil price fluctuations had a large impact on the economy. When an increase in oil prices is usually followed by a recession in the economy and capital markets.

\section{Industrial Production Index}

The industrial production index according to the Central Statistics Agency (BPS) illustrates the total output of manufacturing and mining industries both medium and large scale industries. The industrial production index is used by BPS as the basis for calculating the gross domestic product (GDP). The industrial production index is also an indicator that shows the business cycle in a country. If there is an increase in the industrial production index, the business cycle of a country is undergoing a period of expansion in which company productivity is experiencing an increase and likewise. The increase that occurred in the industrial production index indicated that the economy began to grow better or was in a period of expansion, consistent with the theory of the real business cycle. This condition is considered as the right time for investors to invest in shares.

The industrial production index measures changes in production volume that occurs from various production sectors over time. The measured volume covers almost all production sectors in the country (except agriculture and services) namely mining and quarrying, manufacturing, electricity, gas, and construction. The industrial production index is the information used by an investor to determine the company he will invest. Of course in companies that have good performance and have longterm growth. Research by Beik \& Fatmawati (2014) found a significant positive effect of IPI on JII. The results are consistent with some researchers (Bekhet \& Mugableh, 2012; Hosseini et al., 2011; Hussainey \& Khanh Ngoc, 2009; Hussin et al., 2012; Kwon \& Shin, 1999; Maysami \& Koh, 2000; Mukherjee \& Naka, 1995; Savasa \& Samiloglub, 
2010; Sukmana, 2018). The increase in IPI will affect stock prices through its impact on company profits.

\section{RESEARCH METHODS}

The research's approach used in this study is a quantitative approach that aims to test hypotheses with measurable data and produce conclusions that can be generalized. According to (Sugiyono, 2009), quantitative research can be interpreted as a research method based on positivism philosophy, used to examine particular populations or samples. Data collection is using research instruments to test hypotheses that have been set.

This study examines the impact of the country's risks (consisting of economic, financial, and political risk premiums), exchange rates, world oil prices, industrial production indexes on the Jakarta Islamic Index for the period January 2003 to March 2016. For this purpose, time-series data monthly related to the $\mathrm{JII}$ is obtained from the official website of the BEI. Data from economic, financial, and political risk premiums consisting of country risks, on the other hand, have been obtained from the ICRG. Oil prices, inflation, and industrial production index (IPI) obtained from the official website of BPS. Meanwhile, the sample of this research, the $\mathrm{JII}$, is an index consists of 30 stocks that accommodate Islamic investment law or an index based on Islamic law. The data collection is originated from BEI, in the form of trade index from January 2003 to March 2016.

Indeks $=\frac{\text { Market Value }}{\text { Basic Value }} \times 100$

Country risks (economic, financial, and political) is a concept that explains the possibility of changes in economic and political incidents that tend to produce deviations from the required or expected returns on investments made in a particular country. For political risk, the score of $0.0 \%$ to $49.9 \%$ indicates very high risk; $50.0 \%$ to $59.9 \%$ high risk; $60.0 \%$ to $69.9 \%$ medium risk; $70.0 \%$ to $79.9 \%$ low risk; and $80.0 \%$ or more is considered as very low risk. Economic risk rating of $0.0 \%$ to $24.5 \%$ indicates very high risk; $25.0 \%$ to $29.9 \%$ high risk; $30.0 \%$ to $34.9 \%$ medium risk; $35.0 \%$ to $39.9 \%$ low risk; and $40.0 \%$ or more is measured as very low risk. In addition, $0.0 \%$ to $24.5 \%$ financial risk ratings indicate very high risk; $25.0 \%$ to $29.9 \%$ high risk; $30.0 \%$ to $34.9 \%$ medium risk; $35.0 \%$ to $39.9 \%$ low risk; and $40.0 \%$ or more is reflected as very low risk. The data used monthly data with a percentage of units from the period January 2003 to March 2016. Data were obtained from ICRG.

The exchange rate is the price of one currency measured by another currency. The exchange rate variable used in this study is the rupiah exchange rate against the US dollar, using monthly data from January 2003 to March 2016, and obtained from Bank Indonesia. The world oil price is measured from the spot price of the world oil market which is generally used as the standard, West Texas Intermediate (WTI) or Brent. Crude oil traded at WTI is a high-quality crude oil. This 
world oil price data is monthly data obtained from OPEC which is www.opec.org, with a period from January 2003 to March 2016. IPI is an economic indicator that measures the production of real output. The IPI data in this study are monthly data from January 2003 to March 2016, in the form of an index obtained from the BPS.

The analytical method in this study is Vector Autoregression (VAR) to collects the integration that will be followed by the Vector Error Correction Model (VECM) method. The selection of the VAR/VECM model in this study is studying its theory for researching economic phenomena in the best way (Widarjono, 2013). The research began by launching an integration sequence for all variables by applying the Augmented Dickey-Fuller Test (ADF), the famous root test unit introduced by David Dickey and Wayne Fuller (Ekananda, 2016). If the data used is stationary in the first difference, the VAR model will be combined with the error correction model and directed to VECM. The cointegration test used in this study was developed by Johansen. The test can be used to determine the cointegration of many variables (Widarjono, 2017). After detecting cointegration relationships between variables, long-term and short-term dynamics between variables are analyzed by VECM.

VECM is used to analyze the existence of long-term and short-term relationships between independent and dependent variables in time series data and examine the responses and contributions of each variable. This study uses seven variables, therefore seven equation models can be estimated from VAR or VECM. Each equation estimate for each variable studied. Here are the Jakarta Islamic Index estimation equations:

$$
\begin{aligned}
& \ln J I_{t}=\alpha_{0}+\alpha_{1} \mathrm{FR}_{t}+\alpha_{2} \mathrm{ER}_{t}+\alpha_{3} \mathrm{PR}_{t}+\alpha_{4} \text { KURS }_{t}+\alpha_{5} \text { OILPRICE }_{t}+\alpha_{6} \mathrm{IPI}_{t}+\varepsilon_{t} \\
& \Delta \operatorname{lnJII} t=\alpha_{0}+\alpha_{1} \Delta \mathrm{FR}_{t}+\alpha_{2} \Delta \mathrm{ER}_{t}+\alpha_{3} \Delta \mathrm{PR}_{t}+\alpha_{4} \Delta \mathrm{KURS}_{t}+\alpha_{5} \Delta \text { OILPRICE }_{t}+\alpha_{6} \Delta \mathrm{IPI}_{t} \\
& +\alpha_{7} \mathrm{JII}_{t-i}+\alpha_{0} \mathrm{FR}_{t-i}+\alpha_{9} \mathrm{ER}_{t-i}+\alpha_{10} \mathrm{PR}_{\mathrm{t}-\mathrm{i}}+\alpha_{11} \text { KURS }_{\mathrm{t}-\mathrm{i}}+\alpha_{12} \text { OILPRICE }_{\mathrm{t}-\mathrm{i}} \\
& +\alpha_{13} I P I_{t-i}+\varepsilon_{t}
\end{aligned}
$$

\section{RESULT AND ANALYSIS}

The data of this research uses time series data which is possible to face the problem of false regression. Responding to this it is necessary to do a stationary test of research data. The stationary test in this study with the Augmented Dickey-Fuller (ADF) approach shows all stationary research data at the level of first difference or I (1).

Table 2

Stationary Test

\begin{tabular}{ccccc}
\hline \multirow{2}{*}{ Variable } & \multicolumn{2}{c}{ Level } & \multicolumn{2}{c}{ First Difference } \\
\cline { 2 - 5 } & T-statistich & Prob Adf & T-statistich & Prob Adf \\
\hline LnJII & 1.776012 & 0.9817 & -9.507482 & 0.000 \\
LnPL & 0.578480 & 0.8403 & -12.70726 & 0.000 \\
LnFN & 0.449238 & 0.8102 & -12.79772 & 0.000 \\
LnECO & 0.129057 & 0.7219 & -12.49000 & 0.000
\end{tabular}


Source: EViews Output

$\begin{array}{ccccc}\text { LnKURS } & 1.103697 & 0.9297 & -11.45238 & 0.000 \\ \text { LnOIL } & -0.130014 & 0.6374 & -8.770247 & 0.000 \\ \text { LnIPI } & 0.355838 & 0.7864 & -12.70726 & 0.000\end{array}$

After generating stationary data on I(1), the next step is the cointegration test. The results of the cointegration test carried out by the Johansen test approach that there was a cointegration of long-term relationships between variables.

Table 3

Result of Cointegration Test

\begin{tabular}{ccccc}
\hline Hypothesized & \multicolumn{3}{c}{ Trace } & $\mathbf{0 . 0 5}$ \\
\hline No. of CE(s) & Eigenvalue & Statistic & Critical Value & Prob. ${ }^{* *}$ \\
& & & & \\
None ${ }^{*}$ & 0.281365 & 141.3160 & 125.6154 & 0.0039 \\
At most 1 & 0.179419 & 89.77346 & 95.75366 & 0.1202 \\
At most 2 & 0.160641 & 58.92552 & 69.81889 & 0.2699 \\
At most 3 & 0.082050 & 31.60733 & 47.85613 & 0.6337 \\
At most 4 & 0.063124 & 18.25185 & 29.79707 & 0.5475 \\
At most 5 & 0.050446 & 8.080005 & 15.49471 & 0.4569 \\
At most 6 & $3.22 \mathrm{E}-05$ & 0.005023 & 3.841466 & 0.9425
\end{tabular}

Trace test indicates 1 cointegrating eqn(s) at the 0.05 level

$\begin{array}{ccccc}\begin{array}{c}\text { Hypothesized } \\ \text { No. of CE(s) }\end{array} & \text { Eigenvalue } & \begin{array}{c}\text { Max-Eigen } \\ \text { Statistic }\end{array} & \begin{array}{c}0.05 \\ \text { Critical Value }\end{array} & \text { Prob.** } \\ \text { None }{ }^{*} & 0.281365 & 51.54257 & 46.23142 & 0.0124 \\ \text { At most 1 } & 0.179419 & 30.84794 & 40.07757 & 0.3699 \\ \text { At most 2 } & 0.160641 & 27.31819 & 33.87687 & 0.2467 \\ \text { At most 3 } & 0.082050 & 13.35548 & 27.58434 & 0.8644 \\ \text { At most 4 } & 0.063124 & 10.17184 & 21.13162 & 0.7284 \\ \text { At most 5 } & 0.050446 & 8.074982 & 14.26460 & 0.3711 \\ \text { At most 6 } & 3.22 \mathrm{E}-05 & 0.005023 & 3.841466 & 0.9425\end{array}$

Source: EViews Output

Max-eigenvalue test indicates 1 cointegrating eqn(s) at the 0.05 level

After detecting cointegration between variables, the long-term and shortterm dynamics between the variables would be analyzed with VECM. The result can be shown in Table 4 below.

Table 4

\begin{tabular}{ccc}
\multicolumn{3}{c}{ Table 4 } \\
& VECM Result \\
\hline \multicolumn{3}{c}{ Long Term } \\
\hline Variable & Coefficient & T-statistics \\
LNPL(-1) & 0.907215 & 1.35892 \\
LNFN(-1) & 6.406036 & 6.36577 \\
LNECO(-1) & -4.905220 & -3.29118 \\
LNOIL(-1) & 0.312287 & 1.99095 \\
LNKURS(-1) & 1.997568 & 5.21634 \\
LNIPI(-1) & -2.117643 & -4.19821 \\
\hline
\end{tabular}


Source: EViews Output

\begin{tabular}{ccc}
\hline & Short Term & \\
\hline CointEq1 & -0.070802 & -3.22698 \\
D(LNJII(-1)) & 0.317475 & 3.32916 \\
D(LNJII(-2)) & 0.141036 & 1.34500 \\
D(LNPL(-1)) & -0.888361 & -1.92688 \\
D(LNPL(-2)) & 0.455237 & 1.03872 \\
D(LNFN(-1)) & -0.012742 & -0.04516 \\
D(LNFN(-2)) & -0.030095 & -0.11724 \\
D(LNECO(-1)) & 0.086012 & 0.22761 \\
D(LNECO(-2)) & 0.068337 & 0.18386 \\
D(LNOIL(-1)) & 0.115213 & 1.71689 \\
D(LNOIL(-2)) & 0.011962 & 0.18467 \\
D(LNKURS(-1)) & 0.369031 & 1.59557 \\
D(LNKURS(-2)) & 0.367330 & 1.51709 \\
D(LNIPI(-1)) & -0.014719 & -0.13621 \\
D(LNIPI(-2)) & -0.201897 & -1.90421 \\
\hline Output & &
\end{tabular}

Based on the VECM estimation results above, the ECT value is negative. This result explains there is a long-term equilibrium relationship between variables and the Jakarta Islamic Index. In the short term, when a deviation from the long term occurs, it is corrected by 0.070802 . This is the speed adjustment for returning balance. In the short-term estimation, the effect of the variable is not significant because the time required (lag) for a variable reacts to other variables. The test results prove the existence of an adjustment mechanism from the short run to the long run, which is indicated by significant and negative cointegration errors. Thus a long-term equation is:

$\mathrm{JII}=0.907215 \mathrm{PL}+6.406036 \mathrm{FN}-4.905220 \mathrm{EC}+0.312287 \mathrm{OI}+1.997568 \mathrm{KURS}-$

$$
2.117643 \mathrm{IPI} \text {....(4) }
$$

The long-term estimation results show that political risk has no significant effect on JII. This finding is not in line with Amihud \& Wohl (2004); Kara \& Karabiyik (2015); Madura (2010); Mnif (2017); Vortelinos \& Saha (2016) This indicates that investors ignore the assessment of political conditions measured by the ICRG in investing in Islamic stocks. The long-term estimation results also show that financial risk has a significant effect on JII. The results showed when financial risk increased by $1 \%$ it would increase $\mathrm{JII}$ by 6.406 . This indicates that investors are strongly influenced by financial assessments.

Furthermore, it was concluded that economic risk has a significant negative effect on JII. This result shows that the rise of economic risk by $1 \%$ will reduce the $\mathrm{JII}$ by -4.905 . Interesting things are also found in economic indicators such as industrial production index which has a significant negative effect on the Jll. When the industrial production index increases by $1 \%$, it will reduce the Jakarta Islamic Index by 
2.11. This means the company's performance has decreased when the economy deteriorated, thereby reducing investor interest to invest

World oil prices have a significant effect on the JII. The increase of oil prices by $1 \%$ also increases the Jakarta Islamic Index by 0.312 . The increase in world oil prices pushes the economy and impacts welfare. Considering good welfare tend to increase investment among communities in the form of stock instruments.

Likewise, the exchange rate has a significant effect on the Jll. When the exchange rate increases by $1 \%$, it will increase $\mathrm{JII}$ by 1.997 . The appreciation of the rupiah exchange rate will positively impact the increase in income that is caused by the rise in sales volume. Because of this phenomenon, the company's performance could be affected so that the level of profitability increases and encourage investors to invest in company shares. An increase in stock prices will cause an increase in the stock price index.

\section{The Effect of Financial Risk on the Jakarta Islamic Index}

The ICRG sees five assessments to determine financial risk, namely foreign debt as a percentage of GDP, foreign debt services as a percentage of exports of goods and services, current account as a percentage of exports of goods and services, international liquidity as the closure of imports and exchange rate stability. The estimation results of the VECM show that financial risk is a significant positive influence on the $\mathrm{JII}$ movement in the long run. The results of this study are not in line with previous studies conducted by Clark \& Kassimatis (2004) who examined the country's financial risk and capital market performance in Latin America; that the financial risk premium is a significant variable in explaining stock market performance and rising premiums financial risk has a negative effect on stock returns. The findings of Kara and Karabiyik (2015) state that there is a negative influence of country risk, consisting of the financial; economic; and political risk premium, on share prices in Turkey.

The significant positive impact of financial risk on stock prices can be seen from the indicators of financial risk assessment in Indonesia. Indonesia's debt to GDP ratio during the observation period has improved from year to year. Compared to the debt ratios of other countries, Indonesia is still at a conservative level compared to other countries such as Japan (250.00\%), Greece (176.90\%), Lebanon (139.00\%), Brazil (74.\%), and Argentina 57.10\%. Indonesia's debt to GDP ratio in March 2016 was only $36.47 \%$.

In general, almost all countries take debt, both rich and poor countries, small or large countries. Government debt is an inseparable component of the government's economic policy framework in particular fiscal policy, which could be estimated by comparing the amount of debt to the earnings of a country. Fortunately, Indonesian government debt is still relatively small compared to the debt of most countries. As stated in the Law of State Finance no 17/2003, article 12 
paragraph 3 , that the government loan is limited to a maximum of $60 \%$ of the gross domestic product.

According to an economist analyst from Samuel Sekuritas Indonesia, Lana Soelistianingsih, there was a Maastricht Treaty that provides guidance to see whether a country's external debt is healthy or not. According to this agreement, the ratio of debt to GDP must be below 33\%, which means that the external debt is still in control. If the ratio exceeds $33 \%$ to $60 \%$, then the country must start to be wary of its debt. Likewise, the ratio of the external debt to Indonesian exports is in a conservative position. The ratio of debt to exports is relatively below the normal ratio of $125 \%$, although there was an increase in 2014-2016. In general, during the period of observation, the debt ratio to Indonesia's exports relatively improved. This enhancement causes a positive response from Islamic capital markets such as the $\mathrm{JII}$ as investment gain more attention from investors. The phenomenon also influences the rising in sharia stock prices, particularly in the liquidity of $\mathrm{JII}$.

In sharia's perspective, Al-Quran has been teaching us about managing the risk management of a country through the story of the Prophet Yusuf interpreting the king's dream in his era. The story of the king's dream is told in the letter Yusuf 43, meaning: "The king said (to prominent people of his people): 'Indeed, I dreamed of seeing seven fat cows eaten by seven thin cows and seven green grains and seven other dry grains.' O prominent people: 'Explain to me about the dream of my dream if you can deliver dreams."' (Surah Yusuf: 43). Meanwhile, the interpretation of the Prophet Yusuf to the king's dream is told in Al-Qur'an surah Yusuf verses 46-47 which means: "After the servant met with Joseph he cried: 'Joseph, $O$ people who are very trusted, explain to us about the seven tails fat cows eaten by seven skinny cows and seven green ears (wheat) and other (seven) which are dry so that I return to them, that they may know.' Joseph said: 'So that you plant seven years (forever) as usual; then what you reap should you let it be turned aside except for a little for you to eat."' (Surah Yusuf: 46-47).

Muhammad Quraish Shihab in his book Al-Mishbah interpreted that the Prophet Yusuf understood seven cows as seven years of agriculture. Because cows are used to plow and cow fatness is symbolized as fertility, while thin cows are symbolized as a difficult time in agriculture, namely the clicking period. The availability of each ear of wheat is equal to a year. From the story, it can be seen that the risk management managed the country well. Because of interpretation from the Prophet Yusuf, the country was spared from economic disruption. The Prophet Yusuf suggested to all the people in his country to save a part of the harvest to face the upcoming crisis. Thus the country was protected from the danger of famine and stabilizes both in terms of state finance, economics, and politics. 


\section{The Effect of Economic Risk on the Jakarta Islamic Index}

Economic risk is the most important thing that concerns investors before investing. There are assessments to indicate economic risks, including GDP per head, real GDP growth, annual inflation rate, budget balance as a percentage of GDP, and the current account as a percentage of GDP. In this study, the results display that a significant negative effect occurs between economic risk and JII. This is supported by previous research, namely Kabir Hassan et al. (2003) who tested country risks and stock market volatility, predictability, and diversification in the Middle East and Africa, finding a country's economic risk significantly determines stock volatility and predictability. The significant negative effect between economic risk and the JII is in line with the mainstream paradigm of higher risk which tends to reduce investor motivation stated by Madura (2010). This is also in line with the findings of researches by Kara \& Karabiyik (2015); Mateus (2004) which stated that all country risk factors negatively affect investment decisions on the stock market.

The negative and significant correlation can be explained with the general perspective of high risk. Madura (2010) describes rational investors invest in low-risk countries, release their investments in greater-risk-countries, and avoid investing in countries with extreme risks. Furthermore, a global crisis occurs from July 2007 to May 2009, initially due to the housing crisis in America since 2006. This crisis affected many financial sectors, especially banking and financial markets. The Dow Jones Index even fell by $18 \%$ in one week in America, so did the other developed capital markets such as the Nikkei 225 index and the FTSE 100; it significantly fell by $24 \%$ and $21 \%$ in the same period.

In addition, this global crisis has spread to developing countries, including Indonesia. Composite Stock Price Index (IHSG) fell by $54 \%$ in 2008 . Even BEI had stopped trading after falling $10 \%$ in one day. The Indonesian capital market authority even suspended trade from October 8th, 2009 to October 10th, 2009. Besides, the impact of this crisis not only hit conventional capital markets but the Islamic capital market as well. JII's market capitalization fell by $22 \%$ during the same period (Beik \& Wardhana, 2011). This event was in line with Nezky's (2013) empirical study that conducted that the US crisis had a significant effect on the Indonesian capital market. IHSG responded to the Dow Jones Industrial Average's (DJI) turmoil. The Indonesian capital market is still heavily influenced by foreign capital markets. The shock of a large foreign stock index will cause a response among domestic investors.

Another economic risk assessment is the current account balance or the current account. This indicator is a balance that includes trade in goods and services, income, and current transfers (Kuncoro, 2015). Current transactions are important for a country because they describe the situation of the economy in a country.

Indonesia's current account from year to year has decreased. Even in the 2013 period, there was a deficit of about -3.19 , the largest number from the period 2003 to 2016 . The deficit in the current account means that the strength of imports is 
greater than exports. If a country continues to import for a long period and neglects its exports, the balance of payments would be in danger and reducing the foreign exchange reserves. The reason is exports are a driver of economic activity. On the other hand, based on the budget balance, published by the Organization for Economic Co-operation and Development (OECD), Indonesia's GDP experienced a deficit from 2010 to 2016. The biggest deficit was -2.77 in 2015. Good economic activity will impact a country because it attracts investors to invest.

The result of this study shows that Indonesia's economic risk premium during the observation negatively related to the development of the JII. The decline in investment in the Islamic capital market might decline the price of sharia shares and the index of JII. This study's output is in line with Madura's theory (2010), explaining that rational investors tend to invest in countries with lower risk, release it in countries with greater risks, and avoid investing in countries with extreme risks.

\section{The Effect of Political Risk on the Jakarta Islamic Index}

Political risk is one of the important assessments for investors before investing. In general, political risk has been seen as a non-business risk that commercial companies identify it as a factor that can affect business profitability. Political risks arise from government stability, socio-economic conditions, investment profiles, internal conflicts, external conflicts, corruption, military in politics, religious tensions, law and order, ethnic tensions, democratic accountability, and quality of government bureaucracy.

The results of this study indicate that political risk has an insignificant effect on $\mathrm{JII}$ and it could be seen from the Indonesian corruption index. According to Transparency International, corruption is the behavior of public officials, politicians, or civil servants who improperly enrich themselves or relatives by abusing trusted public power. Law No. 31 of 1999 and Law No. 20 of 2001 concerning Eradication of Corruption, corruption includes (1) state fraud; (2) bribery; (3) embezzlement in office; (4) extortion; (5) cheating; (6) conflicts of interest in procurement; (7) gratification (gift-giving).

Transparency International ranks a country based on corruption that appears between government officials and politicians in the country. This Corruption Perception Index (CPI) is a collection of expert opinions related to corruption and business surveys conducted by several independent and reputable institutions. In the Transparency International record, Indonesia had been included in the ranks of the 10 most corrupt countries in the world. Fortunately, Indonesia was no longer on the list since 2003.

In 2010, Indonesia's CPI ranked 110 out of 180 countries and ranked 5th in ASEAN. In 2011, it improved slightly to 100th in 183 countries. However, in implementing Good Corporate Governance (GCG), Indonesia was in the lowest rank compared to nine other countries in the Asia Pacific region. Hence, to exceed 
economic and social performance, the Indonesian government must professionally implement GCG principles.

Table 5

Indonesia's Level of Corruption

\begin{tabular}{ccc}
\hline Year & CPI & Rank \\
\hline 2000 & 1,7 & $85(90)$ \\
2001 & 1,9 & $84(91)$ \\
2002 & 1,9 & $96(102)$ \\
2003 & 1,9 & $122(133)$ \\
2004 & 2,0 & $133(145)$ \\
2005 & 2,2 & $137(159)$ \\
2008 & 2,6 & $126(180)$ \\
2009 & 2,8 & $111(180)$ \\
2010 & 2,8 & $110(180)$ \\
2011 & 3,0 & $100(183)$ \\
\hline
\end{tabular}

Note: Corruption Perception Index; 0 = worst; 10 = best

Source: Transparency International

Despite the improvement, Indonesia's GPA is still below several ASEAN countries since 2000 , shown on the table below:

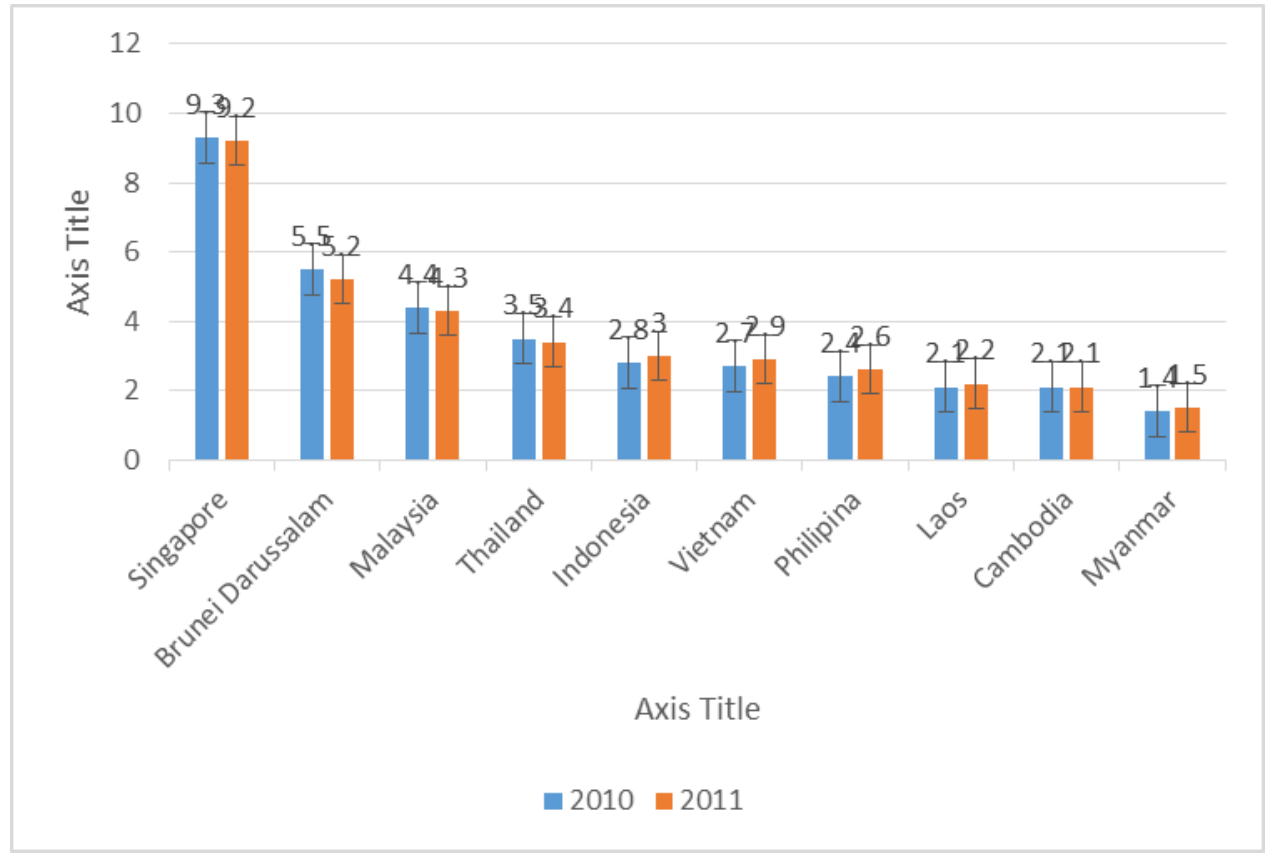

Figure 3. Indonesia's Corruption Rating in Asian Countries

Source: Transparency International

The results show that political uncertainty does not play an important role in determining investors' decisions to invest in bJll. Empirical findings indicate that investors pay less attention to the determinants of political risk before allocating their capital to invest in JII. The results contradict the theory by Madura (2010) and researches by Amihud \& Wohl (2004); Kara \& Karabiyik (2015); Mnif (2017); Vortelinos \& Saha (2016), which stated that political risk has a significant effect on 
stock and index market movements. Also, this insignificant influence opposes the study by Huang et al. (2011) who found an important role in the political crisis in explaining Taiwan's stock market volatility. Dimic et al. (2015) found that political risk factors affected stock market returns in developed countries.

\section{The Effect of the Exchange Rate on the Jakarta Islamic Index}

The estimation results of the VECM model in this study indicate that the exchange rate has a significant positive effect on the Jll movement in the long run. This finding supports the research of Mohamed Asmy et al. (2010) trying to examine the short-term and long-term causal relationships between $\mathrm{KLCl}$ and macroeconomic variables. The results show that the exchange rate significantly affects $\mathrm{KLCl}$. This result also supports the research of Masrizal et al. (2019); Sakti \& Harun (2015) state that in the long run there is a positive relationship between $\mathrm{JI}$ and the exchange rate.

Mishkin (2008) states in his book that demand for securities is influenced by interest rates, wealth, inflation rates, and exchange rates. Indonesia as a country with an open economic system cannot be separated from international transactions and the fluctuation of exchange rates that are generated. In this study, the exchange rate is the value of the US dollar. A decrease in the exchange rate between the rupiah and the dollar means that the US dollar becomes more expensive in rupiah value. This reflects that the value of the US dollar has increased because the amount of rupiah needed to buy dollars has increased. In other words, if the exchange rate rises, the domestic currency will depreciate and the foreign currency will appreciate it. Conversely, the decline in exchange rates reflects the appreciation of the domestic currency and depreciation of foreign currencies.

The relationship between exchange rates and stock prices can be seen from the goods market approach, where changes in the exchange rate will affect company earnings. This will affect the stock price of a company. When the exchange rate depreciates, the cost of imported raw materials for companies will increase. The increase in raw materials will cause production costs to increase and the profitability of the company will decrease so that the dividends obtained by investors decrease. This decrease in dividends results in reduced demand for shares so that stock prices fall. The condition of the decline in stock prices has an impact on the decline in the stock price index.

On the other hand, if there is an appreciation of the rupiah exchange rate, it will have an impact on the increase in income caused by an increase in sales volume. This increase will affect the company's performance so that the level of profitability increases. This will encourage investors to invest in company shares. An increase in stock prices will cause an increase in the stock price index.

The exchange rate of the rupiah to dollar American in the period of this study in the chart below generally underwent appreciation after the Asian crisis in 1998. Thus the rupiah exchange rate has a significant effect on sharia stock prices. Rising 
sharia stock prices, particularly liquid sharia stocks in the Jll sector and also causing the $\mathrm{Jll}$ index to rise.

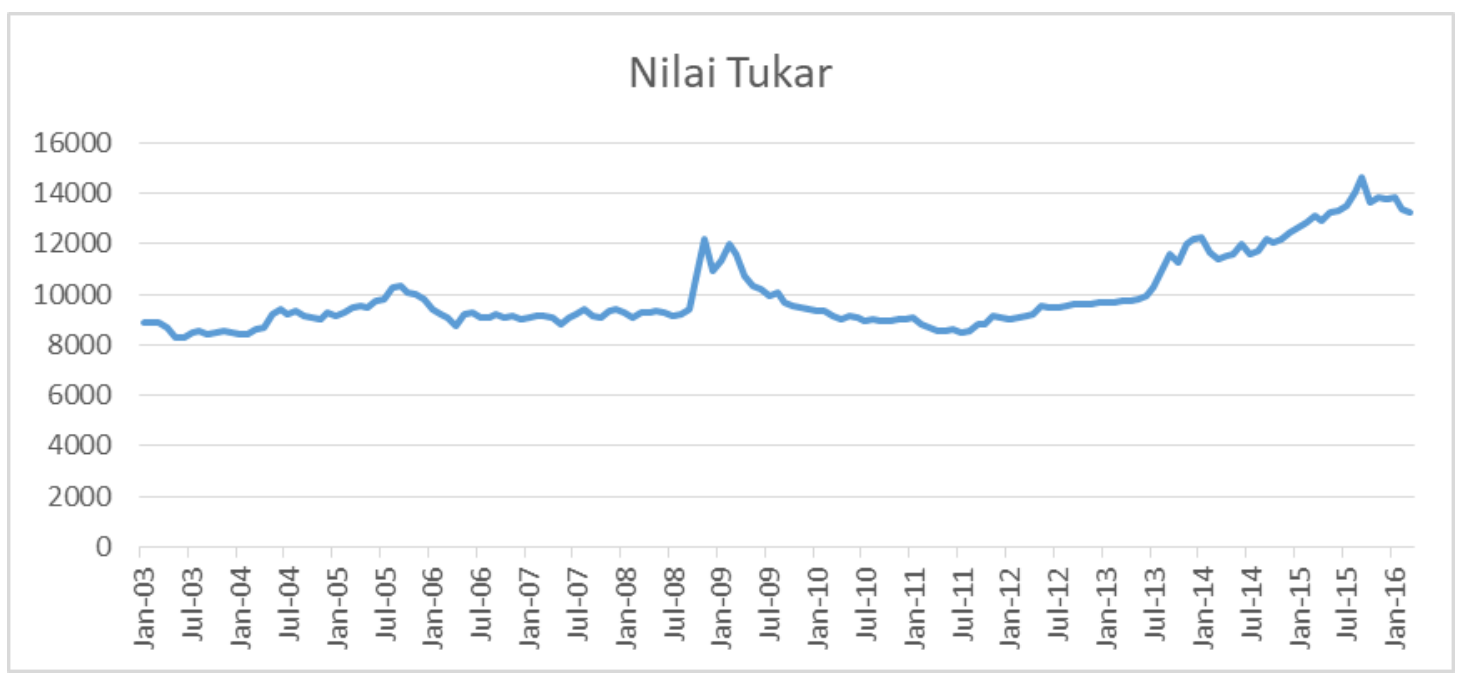

Source: Bank Indonesia

Figure 4. Exchange Rate Movements

From the perspective of Islamic economics, the activity of exchange of money or exchange rates is called sharf. This activity is legally permissible under the DSN MUI fatwa no 28 on Sharf. Thus the legal exchange rate changes with the following conditions: 1) in a fixed exchange rate system, changes in the exchange rate of money, the central bank must set the price of foreign exchange (foreign exchange) and provide or remain willing to buy and sell foreign exchange at an agreed price. If there is a change in demand for one currency, the government (in this case the central bank) should immediately intervene by increasing the supply of one currency whose demand is increasing so that the balance can be maintained; 2) in a flexible exchange rate system or a floating exchange rate system, the government continues to monitor the mechanism of changes in the exchange rate so that speculation or currency value games do not occur or are left free. So that the exchange rate does not surge dramatically due to the absence of government intervention; 3 ) in the exchange of currencies or exchange rates, must meet the conditions specified as the hadith or the proposition of the exchangeability: "Do not sell gold with gold, unless balanced, and do not also sell silver with silver unless it is balanced. Sell gold with silver or silver with gold as you like." (Narrated by Bukhari).

\section{The Effect of World Oil Prices on the Jakarta Islamic Index}

VECM estimation results in this study, especially long-term oil prices have a significant positive effect on the Jakarta Islamic Index (JII). This result is in line with the findings of Roubaud \& Arouri (2018). Two researchers found that oil plays an active role in transmitting price shocks to the stock market. Huang et al. (2011) believe that oil price volatility has a significant effect on stock returns. This result is also in line with Narayan and Narayan's (2010) findings that found a positive and significant impact of oil prices on stock prices. 
The theoretical relationship between oil prices and stock returns can be positive or negative. Several reasons justify the negative correlation between oil prices and stock returns. Oil is the main input of production for most industries. First, higher prices increase production costs, reduce the expected cash flow of the company, reduce income and dividends, and hence, stock returns. Second, higher oil prices can lead to overestimation of inflation and higher nominal interest rates. Because interest rates are used to discount future cash flow estimates, this will depress income and dividends

The high volatility of oil prices causes the sensitivity effect of changes in prices and affects the components of the discount rate, risk premium, and the company's cash flow through demand-side consequences. The main possible reason for a positive relationship between oil prices and stock returns is that investors associate rising oil prices with improved economic conditions. Therefore, higher oil prices can reflect stronger business performance, which has a positive impact on the stock market (Smyth \& Narayan, 2018).

Indonesia was a world oil importer since 2003. However, Indonesia was unable to meet production quotas set by OPEC and considering leaving the organization at the end of 2008. OPEC is a large organization in the world that regulates and oversees oil export and import quotas around the world involving the largest oil-producing countries. Nevertheless, Indonesia still maintains bilateral relations and good cooperation with OPEC countries.

From an economic aspect, Indonesia as an OPEC member is required to pay an annual fee of $U \mathbf{Z} 2$ million, which of course is quite large for Indonesia. Apart from that, the policy of cutting oil production will have an impact on reducing the amount of state revenue and rising oil prices in Indonesia. The increase of oil prices must be followed by the state budget in Indonesia because the decline in state revenue will directly raise the prices of goods and services, causing inflation. Therefore, resigning from OPEC even has a positive effect on the improvement and stability of the state budget.

Thus based on Smyth \& Narayan's (2018) theory that investors associate the rising of oil prices with improved economic conditions. Therefore, oil price volatility can reflect stronger business performance, which has a positive impact on the stock market. This shows that stable oil prices will respond positively to the development of Islamic capital markets such as JII. Such conditions were also triggered by positive sentiment from mining stocks which affected JII. The petroleum mining company is one of the favorable investments to investors who are interested in the sharia effect.

\section{Effect of Industrial Production Index on the Jakarta Islamic Index}

VECM estimation results in this study, especially in the long run, show that IPI has a significant negative effect on the Jakarta Islamic Index (JII). This finding is not in line with the findings obtained from several researchers such as Hussainey \& Khanh 
Ngoc (2009); Hussin et al. (2012); Kwon \& Shin (1999); Maysami \& Koh (2000); Mukherjee \& Naka (1995); Sukmana (2018). The industrial production index, which has a significant effect, shows that the increase of production index is likely to increase the stock index. Growth in industrial production contributed to a positive effect on financial markets which led to higher stock prices and investor optimism.

This significant negative relationship can be seen from the 2008 global crisis triggered by the housing credit scandal in the United States. This crisis dragged the world into an oppressive situation that harmed the economy, including Indonesia. This also happens to the national industrial production sector which relies on imported raw materials because the production costs excelled.

The non-oil and gas export sector and employment are the industrial sectors that greatly contributes to national economic growth. However, a lot of Indonesia's main trading partner countries such as the US; European Union; and Japan, which have imported a lot of various Indonesian products, have been hit hard by the global financial crisis. The people of the countries also affected by the crisis and experienced a decline in financial capacity. The consequence of the financial decline has been the decline in demand for various kinds of goods needed by people in countries affected by the crisis. Because it will prioritize the fulfillment of staple goods.

On the other hand, the decline in liquidity of the US and the rupiah exchange rate will put disadvantages to industries that depend on imported raw materials. Because the industries hardly bring imported raw materials and imported raw materials become more expensive, it will reduce the competitiveness of industrial products in the country. Other impacts are also disrupted plans for expansion and investment by industries in the country.

The impact of difficulties in bringing in raw materials and expensive prices will result in increased production costs by industrial companies, hence the domestic economic growth will be impacted because all of these factors are driving economic growth. The increase in production costs will also impact the company's ability to produce company profitability. The investor will use the information on the industrial production index to determine the company he will invest in, of course in companies that have good performance and have long-term growth. So this will affect investors in deciding investments in the capital market. The decline in investment in the capital market will have an impact on the decline in sharia stock prices, especially sharia liquid stocks in the JII sector, and also cause the JII index to decline.

\section{CONCLUSION}

This study aims to explore the short and long term relationship between the Jakarta Islamic Index (JII) and the macroeconomic variables of the country's risk factors (i.e financial risk, economic risk, and political risk), inflation, oil prices, and industrial production index. This study uses monthly data from January 2003 to March 2016. 
The long-term estimation results show that five variables have a significant effect on JII. Among three positive influential variables are financial risk (LNFN), world oil prices (LNOIL), exchange rates (LNKURS), and two variables that show a negative effect which is risk economics (LNECO) and industrial production index (LNIPI). Meanwhile, the political risk variable (LNPL) has no significant effect. This finding shows that investors consider financial risks, economic risks, and exchange rates in investments. This finding also tells the government that several important macroeconomic indicators need to be considered. This proves that these variables affect the stock index, especially in the long run. These findings recommended the government defended economic and financial stability to increase investor motivation to invest in the capital market.

\section{REFERENCES}

Ahmad, M. (2001). Etika bisnis dalam Islam. Pustaka Al-Kautsar.

Amihud, Y., \& Wohl, A. (2004). Political news and stock prices: The case of Saddam Hussein contracts. Journal of Banking and Finance, 28(5), 1185-1200. https://doi.org/10.1016/j.jbankfin.2003.08.001

Antonakakis, N., Gupta, R., \& Tiwari, A. K. (2017). Has the correlation of inflation and stock prices changed in the United States over the last two centuries? Research in International Business and Finance, 42, 1-8. https://doi.org/10.1016/j.ribaf.2017.04.005

Bahmani-Oskooee, M., \& Saha, S. (2016). Do exchange rate changes have symmetric or asymmetric effects on stock prices? Global Finance Journal, 31, 57-72.

Beik, I. S., \& Fatmawati, S. W. (2014). Pengaruh Indeks Harga Saham Syariah Internasional Dan Variabel Makro Ekonomi Terhadap Jakarta Islamic Index. AlIqtishad: Jurnal Ilmu Ekonomi Syariah, 6(2), 155-178.

Beik, I. S., \& Wardhana, W. (2011). the Relationship Between Jakarta Islamic Index and Other Selected Markets: Jurnal Ekonomi Dan Bisnis Airlangga (JEBA)/ Journal of Economics and Business Airlangga, 21(2), 100-109.

Bekhet, H. A., \& Mugableh, M. I. (2012). Investigating Equilibrium Relationship between Macroeconomic Variables and Malaysian Stock Market Index through Bounds Tests Approach. International Journal of Economics and Finance, 4(10), 69-81. https://doi.org/10.5539/ijef.v4n10p69

Blau, B. M. (2017). The volatility of exchange rates and the non-normality of stock returns. Journal of Economics and Business, 91, 41-52.

Clark, E., \& Kassimatis, K. (2004). Country financial risk and stock market performance: The case of latin america. Journal of Economics \& Business, 56, 21-41.

Delgado, N. A. B., Delgado, E. B., \& Saucedo, E. (2018). The relationship between oil prices, the stock market and the exchange rate: evidence from Mexico. The North American Journal of Economics and Finance, 45, 266-275.

Dimic, N., Orlov, V., \& Piljak, V. (2015). The political risk factor in emerging, frontier, and developed stock markets. Finance Research Letters, 15, 239-245.

Ekananda, M. (2016). Analisis Ekonometrika Time Series. Mitra Wacana Media.

Hammoudeh, S., Mensi, W., Reboredo, J. C., \& Nguyen, D. K. (2014). Dynamic dependence of the global Islamic equity index with global conventional equity 
market indices and risk factors. Pacific Basin Finance Journal, 30, 189-206. https://doi.org/10.1016/j.pacfin.2014.10.001

Hosseini, S. M., Ahmad, Z., \& Lai, Y. W. (2011). The Role of Macroeconomic Variables on Stock Market Index in China and India. International Journal of Economics and Finance, 3(6). https://doi.org/10.5539/ijef.v3n6p233

Huang, H. H., Chan, M. L., Huang, I. H., \& Chang, C. H. (2011). Stock price volatility and overreaction in a political crisis: The effects of corporate governance and performance. Pacific Basin Finance Journal, 19(1), 1-20. https://doi.org/10.1016/j.pacfin.2010.08.001

Hussainey, K., \& Khanh Ngoc, L. (2009). The impact of macroeconomic indicators on Vietnamese stock prices. Journal of Risk Finance, 10(4), 321-332. https://doi.org/10.1108/15265940910980632

Hussin, M., Muhammad, F., \& Awang, S. (2012). Macroeconomic variables and Malaysian Islamic stock market: a time series analysis. The Journal of Business Studies Quarterly (JBSQ), 3(4), 1-13.

Kabir Hassan, M., Maroney, N. C., Monir El-Sady, H., \& Telfah, A. (2003). Country risk and stock market volatility, predictability, and diversification in the Middle East and Africa. Economic Systems, 27(1), 63-82. https://doi.org/10.1016/S09393625(03)00017-7

Kara, E., \& Karabiyik, L. (2015). The Effect Of Country Risk On Stock Prices:An Application In Borsa Istanbul. Süleyman Demirel Üniversitesi Iktisadi ve Idari Bilimler Fakültesi Dergisi, 20(1).

Kwon, C. S., \& Shin, T. S. (1999). Cointegration and causality between macroeconomic variables and stock market returns. Global Finance Journal, 10(1), 71-81.

Madura, J. (2010). International Corporate Finance. Joe Sabatino.

Masrizal, M., Widiastuti, T., Mawardi, I., \& Wisudanto, W. (2019). Analysis of return on equity, current ratio and debt to equity ratio on Islamic stock price Jakarta Islamic Index. Business, Management and Entrepreneurship: Proceedings of the 3rd Global Conference on Business Management \& Entrepreneurship (GC-BME 3), 314.

Mateus, T. (2004). The risk and predictability of equity returns of the EU accession countries. Emerging Markets Review, 5(2), 241-266. https://doi.org/10.1016/j.ememar.2004.03.003

Maysami, R. C., \& Koh, T. S. (2000). A vector error correction model of the Singapore stock market. International Review of Economics and Finance, 9(1), 79-96. https://doi.org/10.1016/S1059-0560(99)00042-8

McEachren, W. A. (2001). Ekonomi Makro: Pendekatan Kontemporer. Salemba Empat.

Mishkin, F. (2008). Ekonomi Uang, Perbankan dan Pasar Keuangan (8th ed.). Salemba Empat.

Mnif, A. T. (2017). Political uncertainty and behavior of Tunisian stock market cycles: Structural unobserved components time series models. Research in International Business and Finance, 39.

Mohamed Asmy, M. T. T., Wisiam, R., Aris, H., \& Md.Fouad, A. (2010). Effects of Macroeconomic Variables on Stock Prices Inmalaysia: an Approach of Error Effects of Macroeconomic Variables on Stock Prices in Malaysia : an Approach of Error. The Global Journal of Finance and Economics, 7(2), 149-168. 
https://mpra.ub.uni-muenchen.de/id/eprint/20970

Mukherjee, T. K., \& Naka, A. (1995). Dynamic relations between macroeconomic variables and the Japanese stock market: an application of a vector error correction model. Journal of Financial Research, 18(2), 223-237.

Naifar, N. (2016). Do global risk factors and macroeconomic conditions affect global Islamic index dynamics? A quantile regression approach. Quarterly Review of Economics and Finance, 61, 29-39. https://doi.org/10.1016/j.qref.2015.10.004

Narayan, P. K., \& Narayan, S. (2010). Modelling the impact of oil prices on Vietnam's stock prices. Applied Energy, 87(1), 356-361. https://doi.org/10.1016/j.apenergy.2009.05.037

Nasution, N. H. \& M. E. (2008). Investasi Pada Pasar Modal Syariah. Kencana.

Nezky, M. (2013). The Impact of US Crisis on Trade and Stock Market in Indonesia. Buletin Ekonomi Moneter Dan Perbankan, 15(3), 83-96. https://doi.org/10.21098/bemp.v15i3.428

Otoritas Jasa Keuangan. (2017). Laporan Perkembangan Keuangan Syariah Indonesia Tahun 2017. https://www.ojk.go.id/id/berita-dankegiatan/publikasi/Documents/Pages/Laporan-Perkembangan-Keuangan-

Syariah-2017/Laporan Perkembangan Keuangan Syariah Indonesia (LPKSI) 2017 (final).pdf

Quran.com. (n.d.-a). Surah Al-Hashr verse 18. https://quran.com/59/18

Quran.com. (n.d.-b). Surah AL-Luqman verse 34. https://quran.com/31/34

Rachmawati, M., \& Laila, N. (2015). Faktor makro ekonomi yang mempengaruhi pergerakan harga saham pada Indeks Saham Syariah Indonesia (ISSI) di Bursa Efek Indonesia (BEI). Jurnal Ekonomi Syariah Teori Dan Terapan, 2(11).

Raza, N., Jawad Hussain Shahzad, S., Tiwari, A. K., \& Shahbaz, M. (2016). Asymmetric impact of gold, oil prices and their volatilities on stock prices of emerging markets. Resources Policy, 290-301. https://doi.org/10.1016/j.resourpol.2016.06.011

Roubaud, D., \& Arouri, M. (2018). Oil prices, exchange rates and stock markets under uncertainty and regime-switching. Finance Research Letters, 27, 28-33. https://doi.org/10.1016/j.frl.2018.02.032

Sakti, M. R. P., \& Harun, M. Y. (2015). Relationship between Islamic Stock Prices and Macroeconomic Variables: Evidence from Jakarta Stock Exchange Islamic Index. Global Review of Islamic Economics and Business, 1(1), 071. https://doi.org/10.14421/grieb.2013.011-06

Savasa, B., \& Samiloglub, F. (2010). The impact of macroeconomic variables on stock returns in Turkey: An ARDL bounds testing approach. Afyon Kocatepe Üniversitesi iktisadi ve Idari Bilimler Fakültesi Dergisi, 12(1), 111-122.

Smyth, R., \& Narayan, P. K. (2018). What do we know about oil prices and stock returns? International Review of Financial Analysis, 57, 148-156.

Suciningtias, S. A., \& Khoiroh, R. (2015). Analisis dampak variabel makro ekonomi terhadap indeks saham syariah indonesia (ISSI). Business, Accounting, And Management (CBAM) (Vol. 2, No. 1), 398-412.

Sugiyono. (2009). Metode Penelitian dan Bisnis. Alfabeta.

Sukmana, R. (2018). Macroeconomic Variables and Stock Indices (Islamic and Conventional): Evidence from Indonesia. 1st International Conference on Islamic Economics, Business, and Philanthropy (ICIEBP 2017), 83-86. 
https://doi.org/10.5220/0007077200830086

Syarif, M. M., \& Asandimitra, N. (2015). Pengaruh Indikator Makro Ekonomi Dan Faktor Global Terhadap Indeks Harga Saham Gabungan (Ihsg). Competence: Journal of Management Studies, 9(2).

Vortelinos, D. I., \& Saha, S. (2016). The impact of political risk on return, Volatility and discontinuity: Evidence from the international stock and foreign exchange markets. Finance Research Letters, 17, 222-226. https://doi.org/10.1016/j.frl.2016.03.017

Widarjono, A. (2013). Ekonometrika Yogyakarta. Upp Stim. Ykpn. 